\title{
Editorial
}

\section{Novas perspectivas \\ em Epidemiologia}

| Kenneth Rochel de Camargo Jr. |

Em função da linha editorial adotada por Physis, definimos um perfil relativamente mais restrito para a aceitação de artigos epidemiológicos. Citando nossa própria definição de escopo editorial: "dada a existência de publicações relevantes nacionais na área de Epidemiologia, o corpo editorial de Physis optou por dar prioridade nesta área a artigos que abordem dimensões conceituais da mesma ou ainda as repercussões sociais dos conhecimentos produzidos pela pesquisa epidemiológica."

Esta decisão não significa de modo algum uma desvalorização da disciplina - a única disciplina própria do campo da Saúde Coletiva, é bom lembrar - mas simplesmente uma avaliação sobre o posicionamento de nossa revista no seu campo. Aproveitando a realização do próximo congresso internacional de Epidemiologia em nosso país, optamos por dedicar o tema deste número àquela disciplina, num trabalho a cargo de Eduardo Faerstein, que faz também a apresentação detalhada do mesmo.

Nos temas livres, Lins e Cecílio apresentam uma contribuição fundamental para a discussão sobre as perspectivas de institucionalização dos processos avaliativos em saúde, amparando-se em sólida revisão com base nas ciências sociais. Segue-se o artigo de Santos sobre pessoas portadoras de deficiência, trazendo uma perspectiva inovadora para a abordagem do tema, com implicações importantes para as concepções de saúde como direito dos cidadãos. Varela e Pierantoni mostram, através de sua análise histórica das transformaçōes recentes do mercado de trabalho em saúde, e comparando-a com o mercado de trabalho em geral, o impacto produzido por políticas de desregulação e flexibilização. Encerrando a seção, Vidal apresenta uma reflexão original sobre a pesquisa qualitativa em saúde, surgida internamente ao próprio processo de pesquisa, onde aborda a emergência do que chama de "analisador natural" a partir do campo, detendo-se nas conseqüências éticas da pesquisa com seres humanos. Encerrando a seção, o artigo de Resende 
propõe uma abordagem filosófica como estratégia de formalização de uma prática terapêutica corporal.

Na seção de resenhas, Chazan nos apresenta em "Uma nova anatomia é destino?" o livro O corpo incerto. Corporeidade, tecnologias médicas e cultura contemporânea, de Francisco Ortega.

Para o último número deste ano (o primeiro número quatro da história de Physis), estamos preparando um tema especial sobre os 20 anos do SUS. Reiteramos o convite à participação de nossos leitores, seja submetendo artigos e resenhas, seja enviando cartas e comentários sobre os artigos publicados em Physis. 